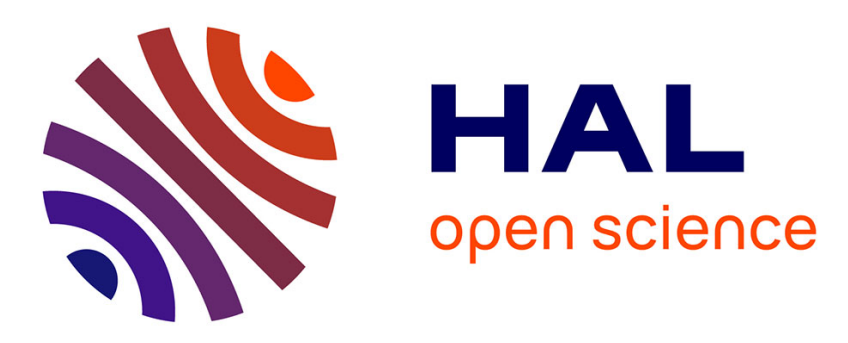

\title{
An up-to-date review of large marine tidal current turbine technologies
}

\author{
Zhibin Zhou, Franck Scuiller, Jean Frédéric Charpentier, Mohamed \\ Benbouzid, Tianhao Tang
}

\section{- To cite this version:}

Zhibin Zhou, Franck Scuiller, Jean Frédéric Charpentier, Mohamed Benbouzid, Tianhao Tang. An up-to-date review of large marine tidal current turbine technologies. IEEE PEAC 2014, IEEE, Nov 2014, Shanghai, China. pp.448-484, 10.1109/PEAC.2014.7037903 . hal-01120817

\section{HAL Id: hal-01120817 \\ https://hal.science/hal-01120817}

Submitted on 26 Feb 2015

HAL is a multi-disciplinary open access archive for the deposit and dissemination of scientific research documents, whether they are published or not. The documents may come from teaching and research institutions in France or abroad, or from public or private research centers.
L'archive ouverte pluridisciplinaire HAL, est destinée au dépôt et à la diffusion de documents scientifiques de niveau recherche, publiés ou non, émanant des établissements d'enseignement et de recherche français ou étrangers, des laboratoires publics ou privés. 


\section{An Up-to-Date Review of Large Marine Tidal Current Turbine Technologies}

\author{
Zhibin Zhou ${ }^{1,2,3}$, Franck Scuiller ${ }^{1}$, Jean Frédéric \\ Charpentier $^{1}$ \\ ${ }^{1}$ French Naval Academy, EA 3634 IRENav, \\ Brest, France \\ Email: zhibin.zhou@ecole-navale.fr
}

\author{
Mohamed Benbouzid ${ }^{2}$ and Tianhao Tang ${ }^{3}$ \\ ${ }^{2}$ University of Brest, EA 4325 LBMS, Brest, France \\ ${ }^{3}$ Shanghai Maritime University, Shanghai, China \\ Email: Mohamed.Benbouzid@univ-brest.fr, \\ thtang@shmtu.edu.cn
}

\begin{abstract}
Owning to the predictability of tidal current resources, marine tidal current energy is considered to be a reliable and promising renewable power source for coastal areas or some remote islands. During the last 10 years, various original horizontal axis and vertical axis marine current turbines (MCT) have been developed around the world. Although various projects have been reported in the state-ofthe-art research papers in recent years, many of these projects were only at the design stage when the papers were published. In fact, some projects do not have any further developments during the several years after the first reporting. In this paper, up-todate information about large tidal turbine projects over $500 \mathrm{~kW}$ is focused. The newest achievements of these large tidal current turbine technologies are presented. These technologies represent the industrial solutions for several pre-commercial MCT farm projects in the coming years. This paper provides a useful background for researchers in the marine turbine energy domain.
\end{abstract}

Keywords - Tidal current turbine, large machine, review.

\section{INTRODUCTION}

One of the main advantages of marine current energy is related to the predictability of the resource. The astronomic nature of tides is driven by the gravitational interaction of the Earth-Moon-Sun system and makes marine tidal currents highly predictable with $98 \%$ accuracy for decades [1]. There are basically two ways of generating electricity from marine tidal energies: either by building a tidal barrage across an estuary or a bay, or by extracting energy from free flowing tidal currents. The main drawback of the solution is that large barrage system would change the hydrology and may have negative impacts on the local ecosystem [2]. Therefore during the last few decades, developers have shifted towards technologies that capture the kinetic energy from tidal-driven marine currents. The exploitable marine current energy with present technologies is estimated about $75 \mathrm{GW}$ in the world and $11 \mathrm{GW}$ in Europe [3].

In fact, various original horizontal axis and vertical axis marine current turbines (MCT) have been developed around the world in recent years [4-6]. The majority of MCT devices are horizontal axis turbines with rotation axis parallel to the

This work is supported by Brest Métropole Océane (BMO) and the Shanghai Maritime University. current flow direction. The main disadvantages associated with vertical axis turbines are relative low self-starting capability, high torque fluctuations and generally lower efficiency than horizontal axis turbine design. Currently, only horizontal axis MCTs appear to be the most technologically and economically solution for large-scale marine current turbines with power capacity over $500 \mathrm{~kW}$.

Although various turbine projects have been reported in some state-of-the-art research papers, many of these projects were only at the design stage when the papers were published [4], [7]. However, some projects are abandoned or never have been built, for instance, the Lunar Energy Tidal turbine. And some projects do not have further developments during the several years after the first announcement, such as Atlantis Resource Nereus and Solon turbines. Therefore, an up-to-date review of industrialized turbine technologies is necessary.

In this paper, up-to-date information and the newest achievements of industrialized large tidal current turbine technologies (over $500 \mathrm{~kW}$ ) will be focused. In Section II, the pilot pre-commercial MCT farms information and the industrialized large turbine technologies are presented. The conclusion and perspective are then given In Section III.

\section{LARGE MARINE CURRENT TURBINE TECHNOLOGIES}

Several horizontal axis turbine technologies are developed more than one or two generations and have been chosen by the industrial communities to realize pilot demonstrative MCT farms before the final commercial stage. These projects illustrate the up-to-date developments of large MCT technologies which will provide electricity to coastal or island areas in the coming years. Table I summarizes the main information about some of these pilot MCT farm projects and their planned/estimated operational dates. From this table, it can be seen that most of these turbine technologies have attended megawatt-level power capacity.

\section{A. OpenHydro Turbine Technology}

OpenHydro is an open-center turbine technology; a 250 $\mathrm{kW}$ prototype was installed and tested at European Marine Energy Center (EMEC) off Orkney islands in Scotland and was connected to the UK national grid in 2008. This turbine 
TABLE I

PILOT MCT FARMS IN THE COMING YEARS [3], [8-10].

\begin{tabular}{|c|c|c|c|c|c|c|}
\hline Companies & Location & Turbine Name & $\begin{array}{c}\text { Pitchable } \\
\text { Blades }\end{array}$ & $\begin{array}{l}\text { Turbine } \\
\text { Number }\end{array}$ & $\begin{array}{c}\text { Total Capacity } \\
\text { (MW) }\end{array}$ & $\begin{array}{c}\text { Operational } \\
\text { Year }\end{array}$ \\
\hline DCNS, EDF & Paimpol-Bréhat & OpenHydro & No & 4 & 2 & $2014 / 2015$ \\
\hline \multirow{2}{*}{ MeyGen } & Pentland Firth & HS1000 & Yes & \multirow{2}{*}{6} & \multirow{2}{*}{6} & \multirow{2}{*}{$2015 / 2016$} \\
\hline & (Scotland) & or AR1000 & No & & & \\
\hline \multirow[t]{2}{*}{ MCT, Siemens } & $\begin{array}{l}\text { Kyle Rhea } \\
\text { (Scotland) }\end{array}$ & SeaGen S & Yes & 4 & 8 & 2015 \\
\hline & Anglesey (Wales) & SeaGen S & Yes & 5 & 10 & 2015 \\
\hline $\begin{array}{l}\text { Andritz Hydro } \\
\text { Hammerfest }\end{array}$ & $\begin{array}{c}\text { Sound of Islay } \\
\text { (Scotland) }\end{array}$ & HS1000 & Yes & 10 & 10 & N/A \\
\hline \multirow{2}{*}{$\begin{array}{c}\text { GDF Suez, Eole } \\
\text { Generation }\end{array}$} & Raz Blanchard & Voith Hytide & No & $3 \sim 6$ & $3 \sim 12$ & 2016 \\
\hline & Fromveur & Sabella & No & N/A & N/A & 2016 \\
\hline
\end{tabular}

technology has been chosen by the French companies EDF and DCNS to build a demonstrative MCT farm off the coast of Paimpol-Bréhat in Brittany, France. The first $500 \mathrm{~kW}$ OpenHydro turbine (Fig. 1) was tested in September 2011 near Brest. This 850 tonnes turbine has a diameter of $16 \mathrm{~m}$ and is supposed to be installed at a depth of 35 meters. This technology uses multi-blades fixed between the open-center rim and the outside shell in a rim-driven configuration. The permanent synchronous generator is integrated into the outside rim shell. The planed MCT farm with 4 turbines is reported to be in operation in 2014 [10]. However, some delays in the final farm operation could still be envisaged.

\section{B. HS1000 and AR1000 Turbine Technologies}

The 1MW pre-commercial turbine HS1000 (Fig. 2) was tested by Andritz Hydro Hammerfest (original Hammerfest Strøm) at EMEC tidal test site at the end of 2011. It started delivering energy to the grid in 2012. The HS1000 turbine is based on the technology of a smaller prototype HS300 (300 $\mathrm{kW}$, reported as E-Tide turbine project in [6-7]) which was installed in Norway and connected to the public grid in 2004. This megawatt-level HS1000 turbine technology is planed to be used in a $10 \mathrm{MW}$ commercial array in the Sound of Islay on the west coast of Scotland; the tidal resource and seabed surveys are completed [13]. This technology is also reported to be chosen in the first phase of the MeyGen tidal current project in Inner Sound of the Pentland Firth [9].

Another candidate for the MeyGen project is the AR1000 turbine (Fig. 3) technology developed by Atlantis Resources Corporation [14]. The Atlantis AR1000 turbine features fixed pitch configuration and is rated at $1 \mathrm{MW}$ at $2.65 \mathrm{~m} / \mathrm{s}$ current velocity. The AR1000 can be rotated in the slack period between tides using a yaw drive for optimally facing the tides. The first AR1000 was successfully deployed and tested at the EMEC facility during the summer of 2011. The AR1000 system is also scheduled to be installed on Daishan demonstration site in China during 2014. A larger turbine called AR1500 (1.5 MW at $3.0 \mathrm{~m} / \mathrm{s})$ is under development for future installation in the Pentland Firth in Scotland and the Bay of Fundy in Canada.

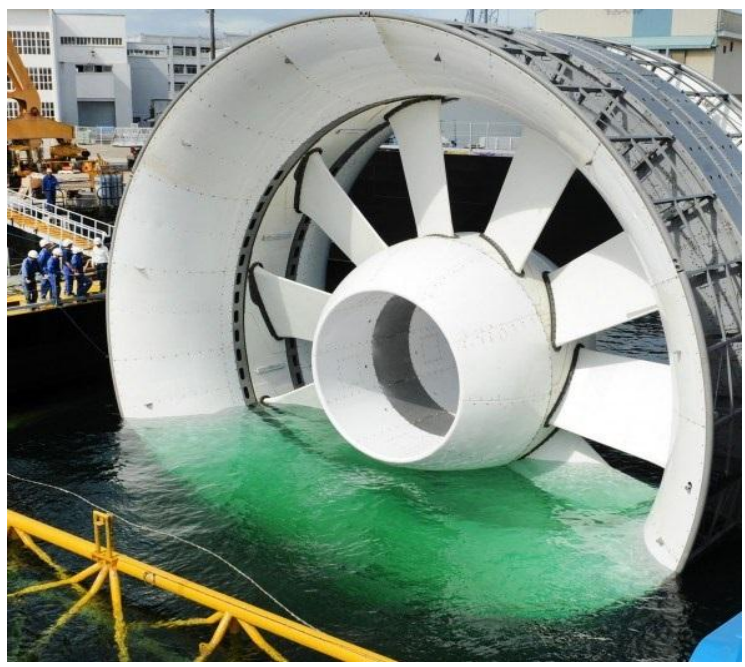

Fig. 1. DCNS-OpenHydro turbine @ [ [11].

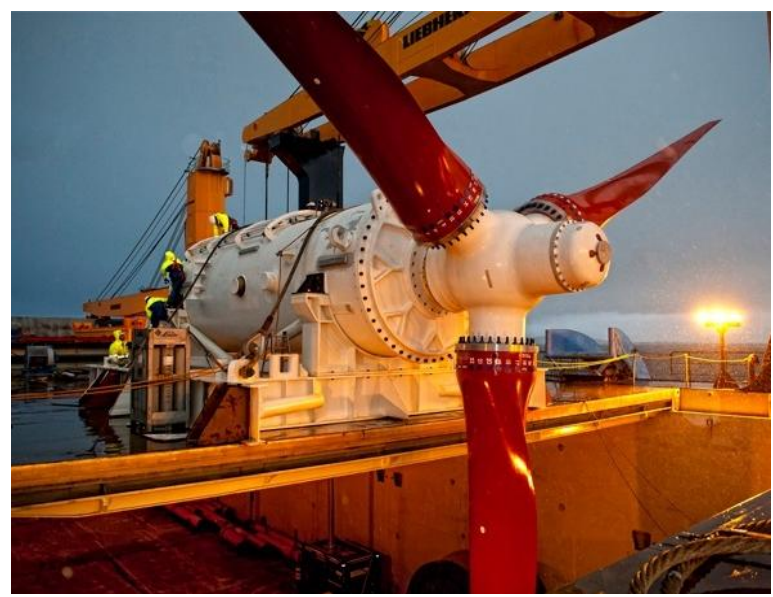

Fig. 2. Andritz Hydro Hammerfest HS1000 turbine (C) [12]. 


\section{SeaGen S Turbine Technology}

The SeaGen S turbine (showed in Fig. 4) developed by Marine Current Turbine Ltd. (owned by Siemens since 2012) is a well-known system that can generate electricity from marine current energy. This technology has a twin axial-flow turbine supported on a structure with the ability to raise the moving components out of the water for maintenance [16]. It is the world first grid-connected megawatt-level MCT system. The 1.2 MW SeaGen S system $(2 \times 600 \mathrm{~kW})$ was installed in Strangford Lough in Northern Ireland in 2008 and has generated $8 \mathrm{GWh}$ electricity since the installation. During a strong spring tide, the SeaGen $\mathrm{S}$ system can deliver more than $20 \mathrm{MWh}$ in a single day. It is reported that up-scaled SeaGen $\mathrm{S}$ systems with 20 meter rotor and $2 \mathrm{MW}$ power rating will be installed in two commercial arrays in UK waters (as listed in Table 1) from 2015.

\section{Voith Hydro Turbine Technology}

French energy company GDF Suez has plans to install pilot tidal energy farms at Raz Blanchard off the coast of Lower Normandy and in the Fromveur passage off the coast of Finistère in Brittany. These two sites represent $80 \%$ of the marine current energy potential in France [17]. For the Raz Blanchard project, GDF Suez has recently confirmed to use Voith Hydro HyTide turbine and Alstom tidal turbine technology. The Voith Hydro turbine system (shown in Fig. 5) is developed by German hydropower equipment maker Voith Company. The first test turbine of $110 \mathrm{~kW}$ has been in operation near the South Korean island of Jindo since 2011. The up-scaled version of $1 \mathrm{MW}$ turbine is now installed and tested at EMEC tidal test site.

The Voith Hydro turbine adopts robust design: it uses fixed-pitch blades and permanent magnet synchronous generator to achieve compact structure. Specially designed symmetric blade profile can be operated for bidirectional tidal currents avoiding pitch and yaw requirements. The nacelle system uses seawater lubrication technology to avoid grease and seals for the bearings. The electrical machine is protected from corrosion and marine fouling by proven coatings and sacrificial anodes. The low-maintenance characteristics makes the estimated system lifetime up to 20 years [18]. The $1 \mathrm{MW}$ turbine has a rotor diameter of $16 \mathrm{~m}$ and reaches the rated power at a current velocity of $2.9 \mathrm{~m} / \mathrm{s}$.

\section{E. Sabella Turbine Technology}

One of the potential MCT applications is to provide electricity for remote islands not connected to the continental electric grid. As example, in the near future, several MCTs are planed to be installed in the Fromveur passage (near Brest) in France to supply part of the load demand of Ouessant Island. For the Fromveur project, the Sabella tidal turbine technology will be used [19]. The Sabella D10 turbines have a rotor diameter of $10 \mathrm{~m}$ and a power capacity of $0.5 \sim 1.1$ MW for 3.0 4.0 m/s current velocities. Figure 6 illustrates the perspective Sabella turbine farm. The Sabella D10 is based on the first French marine current turbine Sabella D03 (3 m rotor diameter) which was tested at Bénodet estuary near Brest in 2008. The prototype D10 turbine is now completing the construction and is scheduled to be installed in the Fromveur passage at the end of 2014. Larger turbines D12 and D15 with power capacities of 1 2 MW are under design for future turbine farm applications [19-20].

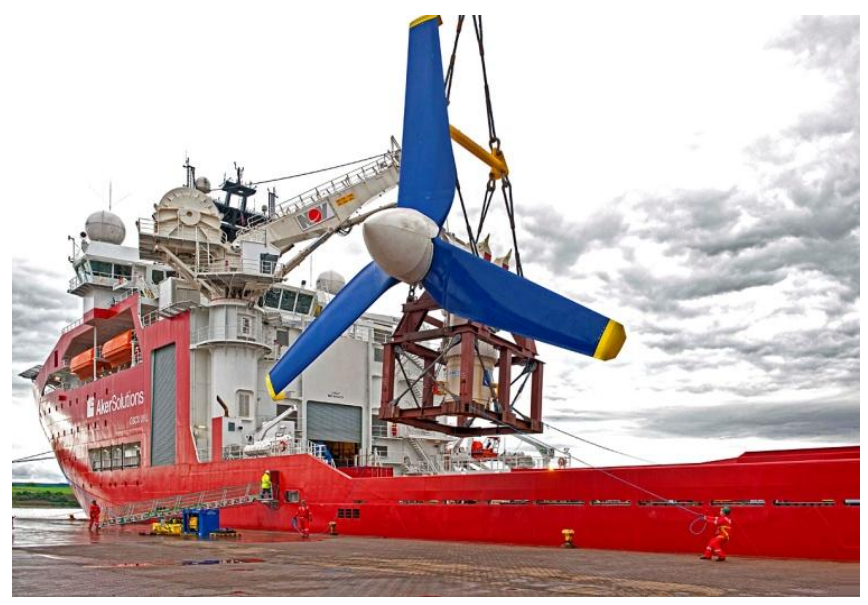

Fig. 3. Atlantis AR1000 turbine (C) [14].

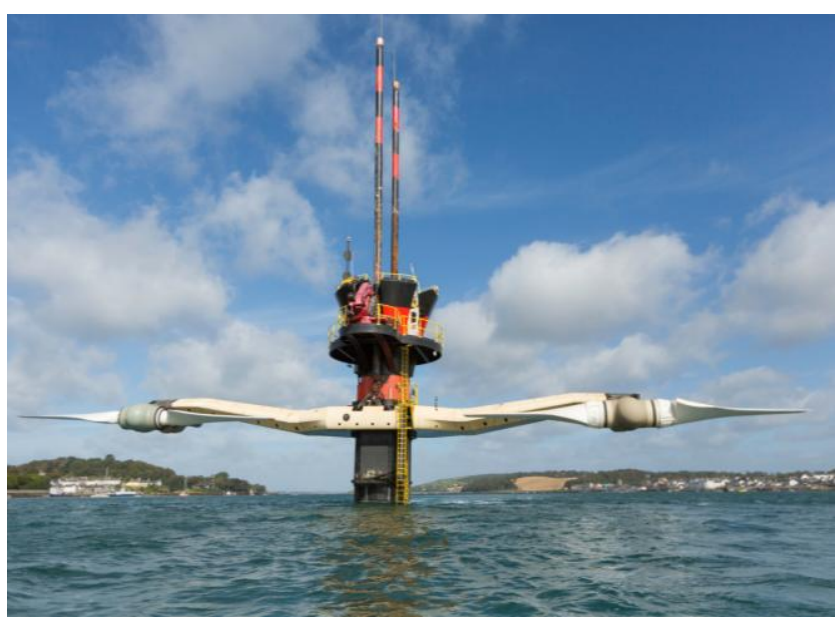

Fig. 4. SeaGen S turbine (C) [15].

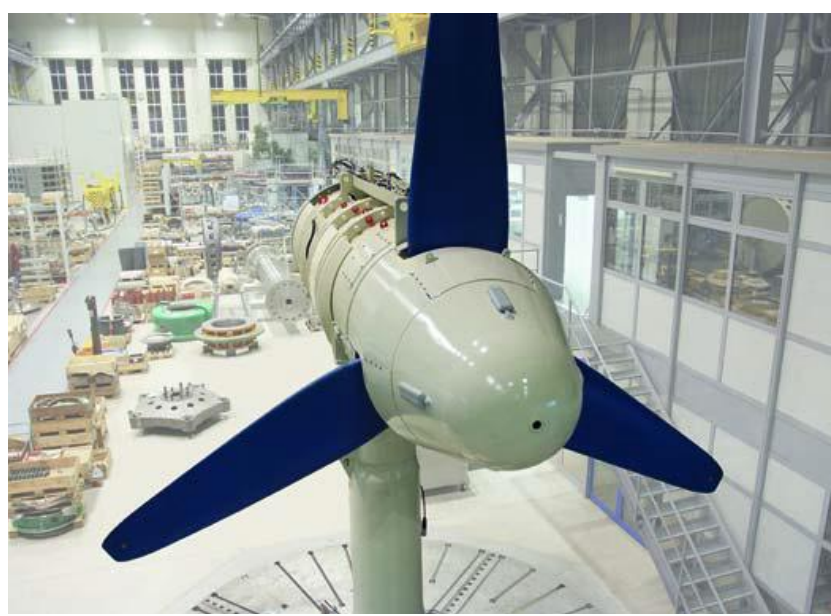

Fig. 5. Voith Hydro turbine (C) [18]. 


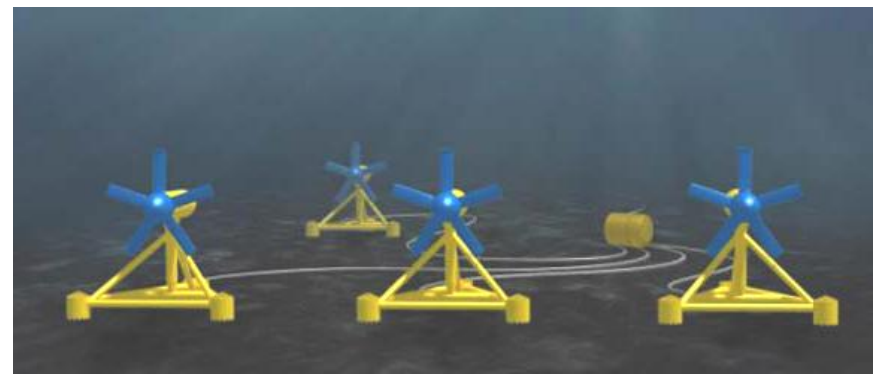

Fig. 6. Sabella turbine farm illustration (C) [20].

\section{F. Alstom Tidal Turbine Technologies}

In 2010, Alstom announced a 1 MW turbine project named Beluga 9 for deployment in Canada's Bay of Fundy in 2012 [21]. Beluga 9 was a joint project with Canadian company Clean Current. It was intended for very powerful currents (up to $4.5 \mathrm{~m} / \mathrm{s}$ ) and for sites with depths of 30 meters or more. However, with the termination of the licensing agreements with Clean Current at the end of 2012, there is no further news about this megawatt turbine project. Clean Current has decided to focus on river turbines and shallower water tidal turbines ( $<20$ meters). While Alstom's intention is to pursue the larger utility scale opportunities [22].

In 2013, Alstom successfully installed a $1 \mathrm{MW}$ tidal current turbine at EMEC tidal test site after the acquisition of Tidal Generation Limited (TGL) [23-24]. Figure 7 shows the Alstom's $1 \mathrm{MW}$ tidal turbine system. This tidal turbine weighs 150 tonnes and has three pitchable blades, a rotor diameter of $18 \mathrm{~m}$ and a nacelle length of $22 \mathrm{~m}$. A standard drive train and power electronics device is inside the nacelle. This turbine system can be installed in a water depth between 35 and 80 meters. It can generate electricity with a tidal current between $1 \mathrm{~m} / \mathrm{s}$ and $3.4 \mathrm{~m} / \mathrm{s}$, and reaches the rated power for a tidal current speed of $2.7 \mathrm{~m} / \mathrm{s}$. This $1 \mathrm{MW}$ Alstom tidal turbine is under extensive testing and analysis in different operational conditions off Orkney islands throughout 2013 over an 18 month period.

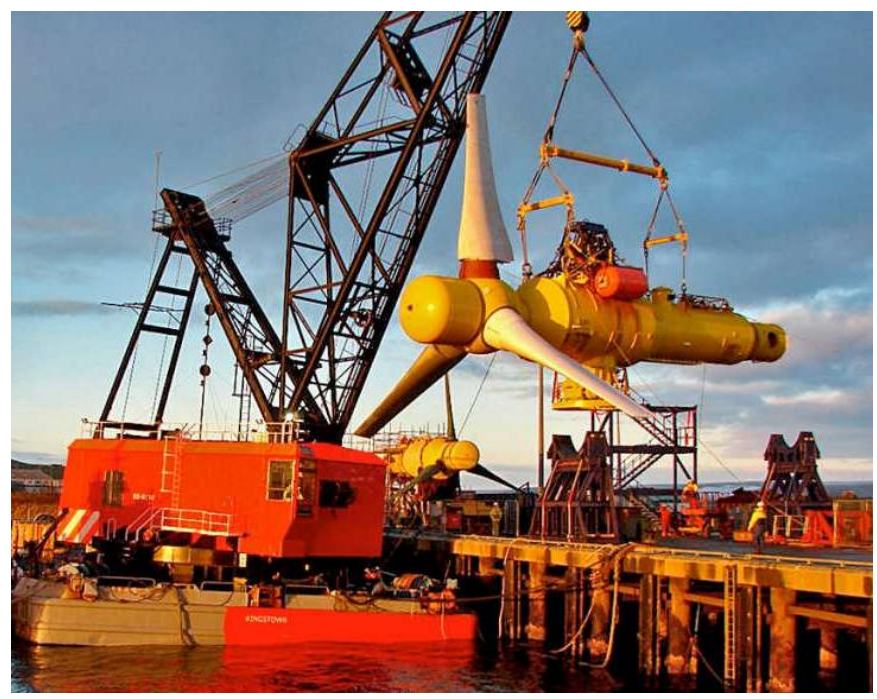

Fig. 7. Alstom tidal turbine (C) [23].
Although the Alstom's 1 MW tidal current turbine seems similar to a standard wind turbine system (with three pitchable blades and gearbox-integrated drive train), this tidal turbine have some special characteristics. Its buoyancy enables the turbine to be easily installed and retrieved by using small vessels, thus reducing the installation and maintenance costs. It has an intelligent nacelle which can be rotated by the water thrusts to orientate the turbine system to face the tide direction; that enables the system to harness energy efficiently from both ebb and flood tides

\section{CONCLUSIONS AND PERSPECTIVES}

The turbines presented above represent the newest achievements in the megawatt-level marine current turbine technologies. The comment point is that they are all horizontal axis turbine. And it should be noted that more than half of these turbine technologies adopt the fixed pitch solution for the blades.

In addition to these industrialized large turbine technologies, there are other megawatt turbine projects under development. For example, the TidalStream Triton technology mounts several turbines on a semi-submersible buoying platform to achieve high power harness capacity. The 1/23rd scale and 1/10th scale turbines (Triton T6 and Triton T3) were successfully tested in 2009 and 2011 respectively [25]. The first full-scale version Triton T36 system (with 2.5 MW power rating) is planned to be built at the Fundy Ocean Research Center for Energy (FORCE) tidal test site in Nova Scotia, Canada.

It should be noted that in FORCE, there are also several megawatt-level current turbine plans which are strongly related to the turbine technologies presented in this paper. High tidal current speed (up to $5.5 \mathrm{~m} / \mathrm{s}$ ) and Nova Scotia's feed-in-tariff make FORCE one of the most attractive and economic tidal sites in the world [26-27]. Siemens and Bluewater are jointly developing a 2 MW floating tidal current turbine, called SeaGen F, to be installed in Bay of Fundy and it will supply electricity for 1,800 Nova Scotia households. OpenHydro, the DCNS tidal subsidiary, will proceed with plans for a grid-connected $4 \mathrm{MW}$ tidal array to be installed at FORCE in later 2015. This array will consist of two $2 \mathrm{MW}$ turbines with $16 \mathrm{~m}$ rotor diameters.

\section{REFERENCES}

[1] S. Benelghali, R. Balme, K. Le Saux, M. E. H. Benbouzid, J. F. Charpentier, and F. Hauville, "A simulation model for the evaluation of the electrical power potential harnessed by a marine current turbine", IEEE Journal of Oceanic Engineering, vol. 32, n 4, pp.786-797, Oct. 2007.

[2] R. Pelc, R.M. Fujita, "Renewable energy from the ocean", Marine Policy, vol. 26, issue 6, pp.471-479, Nov. 2002.

[3] H. Boye, E. Caquot, P. Clement et al., "Rapport de la mission d'étude sur les énergies marines renouvelables," March 2013. (in French)

[4] F.O. Rourke, F. Boyle, A. Reynolds, "Marine current energy devices: Current status and possible future applications in Ireland," Renewable and Sustainable Energy Reviews, vol. 14, n³, pp.1026-1036, Apr. 2010. 
[5] A.S. Bahaj, "Generating electricity from the oceans," Renewable and Sustainable Energy Review, vol. 15, nㄱ, pp.3399-3416, Sept. 2011.

[6] J. Zhang, L. Moreau, M. Machmoum, and P.E. Guillerm, "State of the art in tidal current energy extracting," in Proceedings of the 2014 IEEE ICGE, Sfax (Tunisia), pp. 1-7, March 2014.

[7] S. Benelghali, M.E.H. Benbouzid and J. F. Charpentier, "Marine tidal current electric power generation technology: State of the art and current status," in Proceedings of the 2007 IEEE IEMDC, Antalya (Turkey), vol. 2, pp. 1407-1412, May 2007.

[8] http://www.global-et-local.eu/?Hydroliennes-les-industriels (last accessed August 2014)

[9] http://www.meygen.com/the-project/meygen-news/ (last accessed August 2014)

[10] http://www.renewableenergyfocus.com/view/26574/gdf-suezinvestigates-french-tidal-potential/ (last accessed August 2014)

[11] http://cleantechnica.com/2011/11/14/worlds-largest-tidal-power-arrayoff-french-coast/ (last accessed August 2014)

[12] http://renews.biz/50635/andritz-back-in-action-at-emec/ (last accessed August 2014)

[13] http://www.hammerfeststrom.com/ (last accessed August 2014)

[14] http://atlantisresourcesltd.com/technology/ar-series.html (last accessed August 2014)

[15] http://www.seageneration.co.uk/ (last accessed August 2014)

[16] http://www.siemens.co.uk/en/news_press/index/news_archive/seagentidal-currant-turbine-milestone-hat-trick.htm (last accessed August 2014)
[17] http://www.gdfsuez.com/en/journalists/press-releases/gdf-suez-bolstersplans-for-marine-current-power-france-signing-partnership-agreementalstom/ (last accessed August 2014)

[18] http://voith.com/en/products-services/hydro-power/oceanenergies/tidal-current-power-stations--591.html (last accessed August 2014)

[19] http://www.sabella.fr/ (last accessed August 2014)

[20] http://www.enerzine.com/7/17093+sabella-implante-la-premierehydrolienne-francaise-connectee-au-reseau+.html (last accessed August 2014)

[21] http://www.alstom.com/press-centre/2010/12/alstoms-ocean-energybusiness-established-at-nantes/ (last accessed August 2014)

[22] http://www.cleancurrent.com/news?page=1 (last accessed August 2014)

[23] http://www.sustainableguernsey.info/blog/2013/01/alstom-completespurchase-of-tidal-generation-ltd-from-rolls-royce/ (last accessed August 2014)

[24] http://www.sustainableguernsey.info/blog/2013/03/1-mw-alstom-tidalturbine-generates-grid-electricity-in-orkney-waters/ (last accessed August 2014)

[25] http://www.tidalstream.co.uk/index.html (last accessed August 2014)

[26] http://www.marineturbines.com/News/2014/04/04/siemens-bluewaterand-minas-install-floating-tidal-current-turbines-canadas-bay (last accessed August 2014)

[27] http://social.tidaltoday.com/environmental-permitting/north-americanturbine-testing-picks-speed-regulatory-support-and-hydro-his (last accessed August 2014) 